\title{
Assessing the effect of auditing on bank's financial performance: A panel regression analysis, evidence from Ghana
}

\author{
Beatrice Opoku* Yusheng Wang \\ School of Business Engineering (Finance), Nanjin University of Information, Science and Technology \\ * E-mail of the corresponding author: opokubeatrice20@gmail.com
}

\begin{abstract}
The paper aimed to find if the internal audit committees and their independence have any significant effect on banks' financial performance. The data used in our paper is an annual time series data spanning 2014 and 2019. The study conducted a panel data regression analysis after going through the Hausman test to select the Random Effect model for estimation. The paper again used data six banks selected from the PWC-2019 banking survey. The study presents results that showed that there are some statistically insignificant effects of our main regressor thus Audit, bank's financial performance for selected banks within the period of study. The study rather found bank's cost-to-income ratio have a significant negative effect on financial performance. This is true because the more efficient a bank is, the more it cuts down on avoidable costs to increase its financial performance.
\end{abstract}

Keywords: Audit Independence, Financial Performance and Reporting, Bank Profitability.

DOI: $10.7176 / \mathrm{RJFA} / 12-16-10$

Publication date:August $31^{\text {st }} 2021$

\section{Introduction}

All over the world, the financial sector significantly contributes to the soundness of economies around the world. The financial sector undertakes four core functions including intermediation between surplus and deficit spending units, value exchange, risk transfer, and liquidity thus conversion of assets to cash whilst value is retained. (Reserve Bank of Australia, Financial System Enquiry, 2014). The relative importance of this sector necessitates institution of effective internal controls and measures that engenders regulatory policies to oversee day-to-day activities. These internal and possible external control measures are meant to ensure sustained and increased performance as well as compliance.

Ghana, over the past few years, experienced a surge in the number of banks established raising the total number of Banks to 34 as of 2016 (PWC; Bank of Ghana). Despite the advantages that could be enjoyed due to increased competitiveness in the sector, as a result of sustained and increased performance of each bank, the financial sector over a decade now has been characterized by irregularities that reduced the viability of the financial sector. Ghana's financial sector has been characterized with certain unethical and fraudulent practices. Some banks keep failing at undertaking due diligence before granting loans to customers whilst others misreport on their activities for their personal gains. These unethical practices led to build of non-performing loans, and when a large number of them remained threat, the government came in to save the situation with the financial sector clean-up in 2007.

The financial statement audit, as a monitoring mechanism, helps reduce information asymmetry and protect the interests of the various stakeholders by providing reasonable assurance that the management's financial statements are free from material misstatements. Lower risks on misstatements increase confidence in capital markets, which in turn lowers the cost of capital for firms (Heil, 2012; Watts and Zimmerman, 1986). Internal audit plays an important role in the financial institutions activity, specifically in ongoing maintenance and assessment of internal control, risk management and governance system (Basel Committee on Banking Supervision,

2012). Audit quality plays an important role in maintaining an efficient market environment; an independent quality audit underpins confidence in the credibility and integrity of financial statements which is essential for well-functioning markets and enhanced financial performance. External audits performed in accordance with high quality auditing standards can promote the implementation of accounting standards by reporting entities and help ensure that their financial statements are reliable, transparent and useful. Sound audits can help reinforce strong corporate governance, risk management and internal control at firms, thus contributing to financial performance (Internal Audits Board, 2011).

An independent internal audit reduces the possibilities of management in withholding information for personal use and thus avoiding conflict of interests and fraud (Allegrini and Greco, 2011).The study seeks to investigate 
the effect of auditing on the financial performance of banks in Ghana. Specifically, the study seeks to estimate the effect of auditors' independence on the financial performance of banks in Ghana. It is a matter of fact that before a bank can boast of an independent audit committee there will have be existence of an audit committee. As such an independent audit is adopted to equally infer a presence of audit committee.

The study is organized into five chapters. Chapter one presents an introduction to the study which contains the background of study, problem statement, research objectives and hypotheses, significance and organization of the study. Chapter two outlines an examination of both empirical and theoretical works relevant to the linkages between auditing and bank's financial performance. Chapter three describes the type and sources of data as well as the research methodology. Chapter four then documents the data analysis, interpretation, and discussions. Finally, summary, conclusions and recommendations of the study are presented in Chapter five.

\section{Literature Review and Hypothesis Development}

\subsection{Audit Committee Independence}

An effective functioning audit committee as part of corporate mechanism is required in the separation of corporate ownership and problem of agency conflicts in controlling results. The board of directors comprises audit committee working for the good of corporate governance effectively. The audit committee independence has been a central theme in prior studies. According to these literatures, independence of audit committee improves audit committee monitoring (Lin et al., 2006). As noted in corporate governance code, audit committee contributes significantly to ensure values of firm as a result of the independence and professional conduct of members of the committee is necessary. The association between accounting quality and composition of audit committee was investigated by Bradbury, Mak, and Tan (2006) using a combined sample of Singapore and Malaysia. The outcome of the study showed that audit committee independence improves the quality of earnings.

Therefore, the independence of the audit committee encourages staff to keep up their reputations and provide quality corporate judgment. The ideal situation is for audit committee independence to influence objectives of members, and to become impartial in their assessment of firm financial reporting procedure, external audit process, improve auditor independence and financial position of the firm.

due to methodological differences and data availability, not all relevant studies were found in Ghana. Other studies were known of developed countries where due to data constraints, and common approaches used, literature seem to confirm a common outcome. The review presents outcomes that support the need for effective and efficient presence of auditing for firms across countries.

For instance, Khan and Subhan (2019) outcome suggests that higher audit cost is associated with financial performance i.e., audit function has a positive effect on the firm's financial performance. This is because higher audit cost mostly brings about more efficient audit service which is able to influence the activities of management, positively thus to put them on their toes. Khan and Subhan again presents the fact that board diversity is able to affect financial performance positively. They argue that the presence of female board members contributes to the financial performance of firms. In such situation of having female membership of a board, males are challenge to do their best, to avoid the possibility of females being selected over the males as their head. The ratchet effect leads to a corporate effect of each person's effort on financial performance. The study employed a panel data regression analysis with data from sample companies listed on the Pakistan Stock Exchange (PSE) - 100 indexes, from 2008 to 2017. Return on asset (ROA) and return on equity (ROE) were selected as proxies to measure financial performance of a firm, as their dependent variable. Independent variables for the study included board diversity, and audit quality.

Newman and Comfort (2018) also explored the possible value creation of auditing in a firm and its associated impact on the financial performance of the firm, in their study, investigating the value creation of internal audit and its impact on company performance. By employing a quantitative research methodology with forty (40) employees occupying managerial positions in a sample frame of 25 , their study established a positive relationship of internal auditing with an organization's financial performance. The study therefore recommends that the internal audit function of each firm should be well furnished with needed tools and human resources and that staff are to be well supported.

Aledwan et al. (2015) emphasized the positive effect of audit quality on the financial performance of selected cement firms in Jordan, in their study, the role of audit quality on the relationship between auditor's and financial performance quality of selected cement firms in Jordan. The study revealed that auditor size and auditor independence have a significant impact on the financial performance of these firms in Jordan. The study 
therefore recommends, based on its findings, that firms are able to pay their auditors well and to employ the services of audit firms in good standing and of great integrity. This study presents similar outcome as that of Farouk and Hassan (2014).

In another study, the impact of internal audit function to improve the financial performance of commercial banks in Jordan, by Awdat (2015), the study sought to determine the impact of internal audit function to improve the performance of commercial banks in Jordan. The study identified the financial performance enhancing effect of internal audit on commercial banks in Jordan. According the study, commercial banks in Jordan and elsewhere are urged to develop an internal audit function to maintain the level effective effect in improving financial performance in Ghana. Also, to have positive effect of audit function on a firm's financial performance, a firm must increase the attention of senior management auditors to develop their skills wich help them get abreast with new practices in their works of of identifying, monitoring and measuring risk management. Their study employed a descriptive analytical method with primary data collection from survey with 65 questionnaires to 13 commercial banks - 5 questionnaires for each bank. Finally, Awdat suggest that auditing is able to enhance financial performance of firms when there is proper and adequate sharing of information with respect to internal control procedures that were in place for a given year.

Additionally, Farouk and Hassan (2014), in their study "the impact of audit quality and financial performance of quoted cement firms in Nigeria", examined the relationship between the quality of auditing and financial performance of quoted cement firms in Nigeria. The study used data from each firm's annual financial reports and found out that audit quality has a significant positive effect on financial performance of a firm. In other words the greater the presence and independence of auditing, the greater the likelihood of a firm achieving high profitability. Outcome of their study led to a recommendation to firms - to employ the services of audit firms that have good track record of doing due diligence.

Additionally, Alkhasa (2013) studied to present his work on "the extent to which the internal audit function in the financial and administrative performance in local government bodies adjust to the Gaza Strip: An Empirical Study analytical." This study intended to identify the extent of contribution of the internal audit function in the financial and administrative performance in local government bodies. The study, employed a primary data collection method with survey, using both interviews and questionnaires to generate a sample size of 50 for selected internal auditors working bodies of local government. The results showed that the role of the internal audit function in the financial and administrative performance of local government authorities ensures the validity and accuracy of financial and administrative data, and the commitment of internal auditors which helps to improve the performance of the local government authorities.

This study sought to review other studies in the same vein of establishing this interaction which guarantee firm's profit maximization. The few reviews of related literature provide doubtless outcomes. In most of the studies, audit function has been found to positively impact the financial performance of a firm. Studies such as Neman and comfort (2018), Aledwan et al. (2015), Awdat (2015), Farouk and Hassan (2014), and Alkhasa (2013) confirm the positive significant impact of an audit function nom firms' financial performance. In fact, it comes as a surprise to identify all studies in this context submitting positive impact of an audit function on firms' financial performance, such that firms stand higher chances of gaining more profit the more they employ the services of high ranked auditing firms, which are independent and well remunerated. Also, the review presents another classical outcome suggesting that a female board-member composition helps to put the auditing firm on their toes to work well, ending up with increased firm performance.

Indeed, the achievement of these similar results can be described as robust in the sense that several methods of study were conducted by different persons groups of persons, to present similar results. Methodological differences could not account variations in the outcomes of these reviewed studies. For instance, Farouk and Hassan (2014) and Aledwan et al. (2015) all employed a multivariable regression analysis with the use of a panel dataset. They both achieved same results in support of the need to strengthen the audit function of a firm in order to better position the performance of a firm. Studies that employed a qualitative study with the use of questionnaires in their surveys included Newman and comfort (2018), Awdat (2015), and Alkhasa (2013), among others. If methodological and gender differences were not found to adversely impact the several results of the studies, then respective recommendation are worthy of adhering to. The relationship between audit committee and performance has being examined in prior literature by Puni (2015) investigated and confirms a positive relationship between ROA, ROE and audit committee existence using a sample of Ghana Stock Exchange from 2006 to 2010 .

On the other hand, a few studies that identified a non-significant or negative effect of audit function on firm 
performance were done in Bangladesh, Rouf (2012) studied the relationship between firm value (measured by ROA and ROE), audit committee existence using 93 listed non-financial companies in Dhaka Stock exchange, and found a non-significant relationship. Also, Bremert and Schulten (2009) investigated 160 German listed companies between 2006 and 2007 and found negative association between firm performance and audit committee existence using ROA and Tobin's Q as measures of firm performance and existence of audit committee.

The needs for studies on the association between audit function and firm performance are important for all countries, especially Ghana. This is because of the country's effort in searching for corporate governance mechanisms, reducing bribery and corruption will lead to an improvement in firm and local government authority performances and hence attract more foreign investment. Additionally, strengthening the auditing operations of the financial sector, can further the developmental process of the economy since there will be a reduction in bad debts, non-performing loans that will limit savings, borrowing (due to high rates of interests) and investment.

\section{Data and Research Methods}

The study made use of secondary data for all variables of interest and this research employs a quantitative research design. The study collects data on ROE, return on assets ROA, audit independence (AUDINP), liquidity ratio (LR), capital adequacy ratio (CAR), cost-to-income ratio (CIR) and bank size with total assets (TA) from the 2019 Ghana Banking Survey by the Price Waterhouse Coopers (PWC). The study period from 2014 to 2019 was motivated by the fact not all banks sampled in the study had their financial reports after 2019 available. The panel data multiple regression models for this study will be specified as:

$$
\begin{aligned}
& R_{\text {OE }}=\alpha+\beta(A U D I N P)_{i t}+\gamma(\text { LR })_{i t}+\delta(C I R)_{i t}+\varphi(C A R)_{i t}+\Phi(T A)_{i t}+\mu_{i t} \text { (3) } \\
& R O A_{i t}=\alpha+\beta(A U D I N P)_{i t}+\gamma(I R)_{i t}+\delta(C I R)_{i t}+\varphi(C A R)_{i t}+\Phi(T A)_{i t}+\mu_{i t}
\end{aligned}
$$

Where $\boldsymbol{i}$ and $\boldsymbol{t}$ are the cross sectional and time dimensions respectively of the panel data; $\boldsymbol{A U D I N P}$ it. represents audit committee independence of bank $\boldsymbol{i}$ at time $\boldsymbol{t}$; “ $\boldsymbol{a}$ " and " $\boldsymbol{\alpha}$ " are intercepts for equations (3) and (4) respectively; $\boldsymbol{\pi}_{\boldsymbol{i t}}$ is a proxy for the financial performance of bank $\boldsymbol{i}$ at time $\boldsymbol{t} ; \boldsymbol{\beta}$ measure the effect of audit committee independence at time $\boldsymbol{t}\left(\boldsymbol{A U D I N P} \boldsymbol{P}_{\boldsymbol{i t}}\right)$ for equations (3) and (4) respectively; $\boldsymbol{\gamma}$ measures the effect of bank's liquidity ratio at time $\boldsymbol{t}\left(\boldsymbol{L} \boldsymbol{R}_{i \boldsymbol{i}}\right)$ for equations (3) and (4) respectively; $\boldsymbol{\delta}$ measures the impact of bank's efficiency with cost-to-income ratio at time $\boldsymbol{t} \boldsymbol{\delta}(\boldsymbol{C I R})_{i t}$, measures the effect of capital adequacy ratio $\boldsymbol{\varphi}(\boldsymbol{C A R})_{i t}$ whilst measures the effect of bank size using total assets $\boldsymbol{\Phi}(\boldsymbol{T} \boldsymbol{A})_{i \boldsymbol{i}} ; \boldsymbol{\mu}_{\boldsymbol{i t}}$ is the disturbance term made up of the two error components $\boldsymbol{\alpha}_{\boldsymbol{i}}$ and $\boldsymbol{\varepsilon}_{\boldsymbol{i} \boldsymbol{t}}$ where $\boldsymbol{\alpha}_{\boldsymbol{i}}$ bank specific error component and $\boldsymbol{\varepsilon}_{\boldsymbol{i t}}$ remainder component or the traditional error term 


\section{Summary of variables}

\begin{tabular}{|c|c|c|c|c|c|}
\hline \multirow[t]{2}{*}{ Classification } & \multirow[t]{2}{*}{ Variable } & \multirow[t]{2}{*}{ Notation } & \multirow[t]{2}{*}{ Definition } & \multicolumn{2}{|c|}{$\begin{array}{l}\text { Expected } \\
\text { Sign }\end{array}$} \\
\hline & & & & ROA & ROE \\
\hline \multirow{2}{*}{$\begin{array}{l}\text { Dependent } \\
\text { Variables }\end{array}$} & Return on equity & ROE & Ratio of profit after tax to total equity & & \\
\hline & Return on assets & ROA & Ratio of profit before tax to total assets & & \\
\hline \multicolumn{6}{|l|}{$\begin{array}{l}\text { Independent } \\
\text { Variable }\end{array}$} \\
\hline & $\begin{array}{l}\text { Audit } \\
\text { Independence }\end{array}$ & AI & $\begin{array}{l}\text { Percentage of non-executive members/directors } \\
\text { in the audit committee }\end{array}$ & + & + \\
\hline & \multicolumn{5}{|c|}{ Control Variables } \\
\hline & Bank Size & TA & Measured with total assets of each bank & + & + \\
\hline & $\begin{array}{l}\text { Capital adequacy } \\
\text { ratio }(\%)\end{array}$ & CAR & $\begin{array}{l}\text { Equity capital (Shareholders' Funds) divided by } \\
\text { total assets }\end{array}$ & + & + \\
\hline & Liquidity ratio (\%) & LR & Ratio of liquid funds to total assets & + & - \\
\hline & $\begin{array}{l}\text { Cost-to-income } \\
\text { ratio }(\%)\end{array}$ & CIR & $\begin{array}{l}\text { Ratio of operating expenses to operating } \\
\text { income }\end{array}$ & + & - \\
\hline
\end{tabular}

Table 1: Descriptive statistics

\begin{tabular}{|c|c|c|c|c|c|c|c|c|c|}
\hline Variables & Obs & Mean & Std. Dev. & Min & Max & $\mathrm{p} 1$ & p99 & Skew. & Kurt. \\
\hline RETRUNONASSETS & 30 & 2.76 & 2.363 & -3.7 & 7 & -3.7 & 7 & -.808 & 3.867 \\
\hline RETURNONEUITY & 30 & 19.186 & 16.034 & -23.34 & 46 & -23.34 & 46 & -.822 & 3.581 \\
\hline AUDIT & 30 & 1 & 0 & 1 & 1 & 1 & 1 & $\cdot$ & • \\
\hline AUDINP & 30 & 130.033 & 164.499 & 100 & 1001 & 100 & 1001 & 5.199 & 28.034 \\
\hline LIQUIDITYRATIO & 30 & 63.458 & 30.278 & 34 & 144.9 & 34 & 144.9 & 1.806 & 5.346 \\
\hline & 28 & 57.907 & 16.685 & 35 & 101 & 35 & 101 & 1.093 & 3.657 \\
\hline COSTTOINCOMERATIO & 30 & 18.109 & 4.496 & 10.48 & 28.48 & 10.48 & 28.48 & .479 & 2.252 \\
\hline $\begin{array}{l}\text { CAPITALADEQUACYR } \\
\text { ATIO }\end{array}$ & & & & & & & & & \\
\hline LNTA & 30 & 16.036 & 2.076 & 14.332 & 22.215 & 14.332 & 22.215 & 2.32 & 7.081 \\
\hline
\end{tabular}

Table 2: Correlation analysis

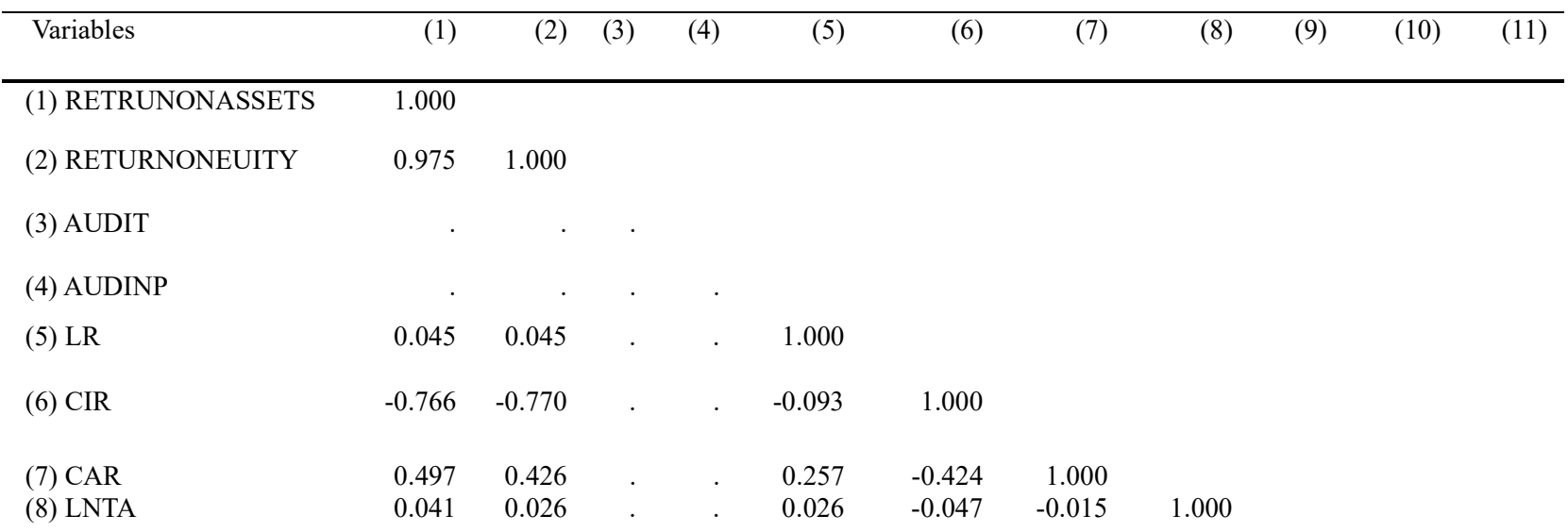


To help determine whether the panel calculation assumes a fixed effect or a random effect model, the Hausman test was carried out. This section presents the discussion of the outcome of the Hausman test. The Hausman test examines the consistency of the GLS (random effects) estimates. The null hypothesis is that the random effects estimates are consistent — that is, that the disturbances and explanatory variables are independent. Hausman test was performed, and its results is presented in Table 3

Table 3: Hausman test

\begin{tabular}{lr}
\hline & Coef. \\
\hline Chi-square test value & 3.802 \\
P-value & .802 \\
\hline
\end{tabular}

Therefore, do not reject the null hypothesis of random effects because of P-value more than the 5\% significance level.

According to the results of the Hausman test, the random effects model is more suitable to estimate equations the studies audit independence and bank profitability, relating to the development characteristics of different banks in Ghana. The random effects model thereby overcomes the constant intercept assumption of the Pooled effect and makes room to accept the premise of different intercepts for each bank. The individual differences is accommodated by the error term of each bank under study.

The Hausman test shows that the random effect model is more appropriate for the estimation because the p-value of the test is greater than 0.05 (see Table 4.2): the null hypothesis of the Hausman test is not rejected. This implies that, because there is no systematic discrepancy between the coefficients of the estimation of the fixed effect and the estimation of the random effect, as shown in Table 3 the random effect model is used in our estimation.

3.1 Results of Multiple Linear Regression Analysis

Table 4: Regression results

\begin{tabular}{lcc}
\hline & $(1)$ & $(2)$ \\
VARIABLES & RETRUNONASSETS & RETURNONEUITY \\
\hline \multirow{2}{*}{ AUDINP } & 0.0581 & 0.303 \\
& $(0.0416)$ & $(0.293)$ \\
LIQUIDITYRATIO & -0.00942 & -0.0467 \\
COSTTOINCOMERATIO & $(0.0115)$ & $(0.0813)$ \\
& $-0.0807^{* * *}$ & $-0.608^{* * *}$ \\
CAPITALADEQUACYRATIO & $(0.0226)$ & $(0.159)$ \\
& $0.172^{* *}$ & 0.744 \\
LNTA & $(0.0820)$ & $(0.579)$ \\
& 0.00142 & -0.136 \\
Constant & $(0.168)$ & $(1.182)$ \\
& -0.658 & 17.43 \\
Observations & $(6.112)$ & $(43.12)$ \\
Number of bankmum & & 28 \\
\hline
\end{tabular}

The hypothesis of existence of audit committee and its independence has a statistically insignificant effect on bank financial performance in Ghana, between the years of study. The independence of audit independence is recorded whether or not ROA and ROE is being used as a measure of banks' financial performance. Only bank specific variables like cost-to-income ration and capital adequacy ratio exert a statistically significant effect on banks' performance. According to the results an increase in cost-to-income ratio which measures efficiency leads 
to a decrease in bank performance by 8percent, ceteris paribus. The more efficient a bank is, the more it improves its financial performance. The same an increase in capital adequacy ratio of each bank leads to 17 precent increase in bank's performance. The findings of our study are rather at odds to the findings of other studies (Khlif and Samaha, 2014; McMullen, 1996; Samaha, Khlif and Hussainey, 2015), in which an independent audit committee has a positive impact on fulfilling the needs of investors to have accurate information on the company and contributes to higher performance.

\section{Conclusion}

In the Table 4, we present our panel data regression result for random effects. The study analyzed the effects of the internal audit committee' independence on banks' financial performance in Ghana between 2014 and 2019 for six (6) universal commercial banks. These banks include Agricultural Development Bank, Cal Bank, Ecobank, Ghana Commercial Bank, Societe General Banks from 2014-2019 period. The study's finding shows that if there is a non-executive director as a member in the internal audit committee (represented in the paper by the internal audit independence variable AUDINP) then there is an insignificant effect on the bank's financial performance. Audit independence is not explaining firms' financial performance because the study had used banks that have a well-established and a strong internal committee and also requesting an external auditor at certain times. Bank efficiency has rather proven to influence firms' financial performance.

\section{References}

study of manufacturing sector of Pakistan," Business Review, Vol. 10, No. 1, 102-114, 2015

A. A. Awdat, "The impact of the internal audit function to improve the financial performance of commercial banks in Jordan," Research Journal of Finance and Accounting, vol. 6, No. 3, pp. 217-225, 2015.

A. Ebrahim, "Earnings management and board activity: An additional evidence," Review of Accounting and Finance, vol. 6, No. 1, pp. 42-58, 2007.

A. M. Hamdan, A. M. Sarea, and S. M. R. Reyad, "The impact of audit committee characteristics on the performance: Evidence from Jordan,” International Management Review, vol. 9, No. 1, pp. 32-41, 2013.

A. Rouf, "The Relationship between Corporate Governance and Value of the Firm in Developing Countries: Evidence from Bangladesh," Journal of Economics and Business Research, vol. 18, No. 1, pp. 73-85, 2012.

A. W. Khan and Q. A. Subhan, "Impact of board diversity and audit on firm performance," Cogent Business and management, vol. 6, 2019.

B. A. Aledwan, A. A. Bani Yaseen, and A. Alkubisi, "The role of audit on the relationship between auditor's and financial performance quality of selected cement firm in Jordan," International Journal of Business and Social Science," vol. 6, No. 12, December 2015.

B. D Kiabel, "Internal auditing and performance of government enterprises: A Nigerian study," Global Journal of Management and Business Research, vol. 12 No. 6, March 2012.

Bradbury, M. E. (1990). The incentives for voluntary audit committee formation. Journal of Accounting and Public Policy, 9(1), 19-36.

C. Ghafran, and N. O'Sullivan, "The governance role of audit committees: reviewing a decade of evidence," International Journal of Management Reviews, vol. 15, No. 4, pp. 381-407, 2013.

E. M. Al-Matar, A. K. Al-Swidi, and F. H. B. Fadzil, "The effect of board of directors characteristics, audit committee characteristics and executive committee characteristics on firm performance in Oman: An empirical study," Asian Social Science, vol. 10 No. 11, 2014.

I. Glover-Akpey, and A. B. Azembila, "The Effect of Audit Committees on the Performance of Firms Listed on the Ghana Stock Exchange,”. Journal of Business and Management, Vol. 18, No. 11, pp. 55-62, 2016.

J. Bedard, S. M. Chtourou, and L. Courteau, "The effect of audit committee expertise, independence, and activity on aggressive earnings management. Auditing," Journal of Practice \& Theory, vol. 23, No. 2, pp. 13-35, 2004 
J. L. Abernathy, B. Beyer, A. Masli, and C. Stefaniak," "The association between characteristics of audit committee accounting experts, audit committee chairs, and financial reporting timeliness," Advances in Accounting, vol. 30 No. 2, pp. 283-297, 2014.

J. R. Cohen, L. M. Gaynor, G. Krishnamoorthy, and A. M. Wright, "The impact on auditor judgments of CEO influence on audit committee independence," Auditing: A Journal of Practice \& Theory, vol. 30, No. 4, pp. 129$147,2011$.

J. V. Carcello, and T. L. Neal, "Audit committee composition and auditor reporting," The Accounting Review, vol. 75, No. 4, pp. 453-467, 2002.

L. J. Abbott, S. Parker, and G. F. Peters, "Audit committee characteristics and financial misstatement: A study of the efficacy of certain blue ribbon committee recommendations," SSRN 319125, 2002.

L. J. Abbott, Y. Park, and S. Parker, "The effects of audit committee activity and independence on corporate fraud," Managerial Finance, vol. 26 No.11, pp. 55-68, 2000.

M. A. Farouk and S. U. Hassan, "Impact of audit quality and financial performance of quoted cement firms in Nigeria,” International Journal of Accounting and Taxation, vol. 2, pp. 01-22, June 2014.

M. Amer, "|Measuring the effect of the board of directors and audit committee characteristics on firm financial performance in Egypt,” Doctoral dissertation, Cardiff Metropolitan University, 2016.

M. Bradbury, Y. T. Mak, and S. M. Tan, "Board characteristics, audit committee characteristics and abnormal accruals," Pacific Accounting Review, vol. 18, No. 2, pp. 47-68, 2006.

M. Gibbins, S. McCracken, and S. E. Salterio, "The auditor's strategy selection for negotiation with management: Flexibility of initial accounting position and nature of the relationship," Accounting, Organizations and Society, vol. 35, No. 6, pp. 579-595, 2010.

M. L. DeFond, R. N. Hann, and X. Hu, "Does the market value financial expertise on audit committees of boards of directors?,” Journal of Accounting Research, vol. 43, No. 2, pp. 153-193, 2005.

N. Bansal, and A. K. Sharma, "Audit Committee, Corporate Governance and Firm Performance: Empirical Evidence from India,”.International Journal of Economics and Finance, vol. 8, No. 3, 2016.

N. W. Muchiri and A. Jagongo, "Internal auditing and financial performance of public institutions in Kenya: A case study of Kenya Meat Commission,” African Journal of Business and Management,' vol.11 No. 8, pp. 168174, Aprril 2017.

O. S. Aanu, I. F. Odianosen and O. I, Foyeke, "Effectiveness of audit committee and firm financial performance in Nigeria: An empirical Analysis," Journal of Accounting and Auditing: Research and practice, vol. 2014, pp. 1 $-12,2014$.

S. K. Aikins, “An examination of Government internal audits' role in improving financial performance,” vol. 11, No. 4, pp. 306-337, 2011.

S. R. Kipkoech and L. Rono, "Audit committee size, experience and firm financial performance. Evidence Nairobi Securities Exchange, Kenya,” Research Journal of Finance and Accounting, vol. 7, No. 15, 2016.

W. Newman, and M. Comfort, "Investigating the value creation of internal audit and its impact on company performance,” Academy of Entrepreneurship Journal, vo.. 24 pp. No. 3, 2018.

Z. Bouaziz, and M. Triki, "The impact of the presence of audit committees on the financial performance of Tunisian companies,” International Journal of Management and Business Studies, vol. 2, No. 4, pp. 57-64, 2012. 